\title{
PENGARUH KOMPENSASI, PROMOSI JABATAN, DAN MOTIVASI KERJA TERHADAP KINERJA KARYAWAN BAGIAN PRODUKSI PT. MEGA SYNERGY POWERINDO BATAM
}

\author{
Tri Anisah ${ }^{1)}$, Sri Langgeng Ratnasari ${ }^{2)}$ \\ ${ }^{1}$ Program Studi Manajemen, Universtas Riau Kepulauan \\ email: trianisah@yahoo.com \\ ${ }^{2}$ Program Studi Magister Manajemen, Universitas Riau Kepulauan \\ email: sarisucahyo@yahoo.com
}

\begin{abstract}
ABSTRAK
Penelitian ini bertujuan untuk mengetahui pengaruh kompensasi, promosi jabatan, dan motivasi secara parsial dan secara simultan terhadap kinerja karyawan bagian produksi PT. Mega Synergy Powerindo Batam. Penelitian ini merupakan penelitian deskriptif dengan pendekatan kuantitatif. Populasi penelitian ini sebanyak 50 karyawan. Sampel penelitian ini berjumlah 50 responden. Teknik samplingnya menggunakan teknik sensus. Hasil pengujian secara parsial variabel kompensasi nilai $\mathrm{t}$ hitung 2,530 $>\mathrm{t}$ tabel 1,679 dan nilai signifikannya $0,015>0,05$, variabel promosi jabatan nilai $\mathrm{t}$ hitung 3,237 $>\mathrm{t}$ tabel 1,679 dan nilai signifikannya $0,002<0,05$, variabel motivasi kerja nilai $\mathrm{t}$ hitung $0,408<\mathrm{t}$ tabel 1,679 dan nilai signifikannya $0,685>0,05$. Artinya variabel ketiga yaitu motivasi kerja $\mathrm{H} 0$ ditolak. Hasil Pengujian secara simultan, nilai $\mathrm{f}$ sebesar $\mathrm{f}$ hitung $1,095<2,81 \mathrm{f}$ tabel dan nilai probalitas signifikan sebesar $0,370>0,05$ sehingga artinya variabel kompensasi, promosi jabatan dan motivasi kerja tidak berpengaruh secara simultan terhadap variabel kinerja karyawan.
\end{abstract}

Keywords: Kompensasi, Promosi Jabatan, Motivasi Kerja, Kinerja Karyawan

\section{PENDAHULUAN}

Kompensasi merupakan suatu hal yang wajib dipenuhi perusahaan untuk karyawan dengan berlandaskan undangundang negara, peraturan dan ketentuan dari perusahaan.

Perbedaan nilai atau jumlah yang diterima karyawan dengan status atau jabatan, pendidikan, sertifikasi dan skill yang sama membuat beberapa karyawan sering melakukan komplain terhadap perusahaan melalui staf lapangan. Hal ini membuat karyawan merasakan ketidak adilan dan menyebabkan menurunnya motivasi karyawan ditandai dengan seringnya karyawan pulang setengah hari dan terlambat. Pembagian gaji karyawan yang sering kali mengalami keterlambatan dan tidak adanya bonus tahunan ataupun bonus projek menjadikan karyawan termotivasi untuk melakukan demo gaji, mogok kerja dan memutuskan perjanjian sepihak (resign). Hal ini mempengaruhi tercapainya target produksi perusahaan. Setiap karyawan harus mendapatkan hak yang sama tanpa terkecuali, untuk melakukan pengembangan SDM dapat dilakukan dengan banyak cara, salah satunya adalah promosi jabatan. Hal ini dipercaya akan mengoptimalkan dan memotivasi SDM yang dimiliki perusahaan karena merasa dihargai, diperhatikan dan diakui kemampuan kerjannya.

Promosi jabatan tidak hanya memberikan kesempatan kepada karyawan yang berkompeten, tetapi juga kepada karyawan lama, tetapi mereka kurang mendapat kesempatan dikarenakan sebagian besar karyawan lama adalah karyawan permanen. Salah satu motivasi dari karyawan adalah kompensasi. 


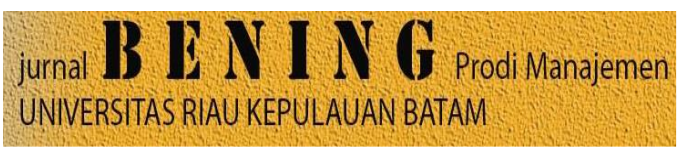

Kompensasi sangat penting bagi karyawan sebagai individu, karena besarnya kompensasi merupakan pencerminan atau ukuran nilai pekerjaan karyawan itu sendiri. Apabila kompensasi diberikan secara tepat dan benar, maka dapat meningkatkan dan menumbuhkan motivasi dalam diri karyawan untuk membantu perusahaan dalam mencapai tujuannya.

Motivasi kerja sangat berperan penting dalam pencapaian target produksi. Beberapa faktor yang bisa mempengaruhi kinerja karyawan yaitu stress kerja, tekanan dari atasan, dan kompetensi. Stres yang terlalu besar dapat mengancam kemampuan seseorang untuk menghadapi lingkungan.

Hipotesis penelitian ini sebagai berikut:

H1: Kompensasi berpengaruh signifikan terhadap kinerja karyawan PT. Mega Synergy Powerindo Batam.

H2: Promosi jabatan berpengaruh signifikan terhadap kinerja karyawan PT. Mega Synergy Powerindo Batam.

H3: Motivasi berpengaruh signifikan terhadap kinerja karyawan PT. Mega Synergy Powerindo Batam.

H4: Kompensasi, promosi jabatan, dan motivasi secara simultan berpengaruh signifikan terhadap kinerja karyawan PT. Mega Synergy Powerindo Batam.

\section{METODE PENELITIAN}

Populasi adalah wilayah generalisasi yang terdiri dari objek-objek yang mempunyai kualitas dan karakteristik tertentu yang ditetapkan oleh peneliti untuk dipelajari dan kemudian ditarik kesimpulannya, Sugiyono (2016).

Populasi dalam penelitian ini adalah karyawan bagian produksi PT. Mega Synergi Powerindo yang berjumlah 50 orang.

Menurut Sugiyono (2016) menyatakan sampel merupakan bagian dari jumlah dan karakteristik yang dimiliki oleh populasi. Pada penelitian ini sampelnya sebanyak 49 orang, dikarenakan jumlah karyawan tidak
Volume 6 No. 2 Tahun 2019

P-ISSN 2252-5262

E-ISSN 2614-499

melebihi dari 100 orang. Teknik pengumpulan sampel menggunanakan teknik sensus seluruh populasi penelitian.

Teknik pengumpulan data merupakan cara-cara yang dilakukan untuk memperoleh data dan keteranganketerangan yang diperlukan dalam penelitian.

\section{HASIL DAN PEMBAHASAN}

\section{Uji Validitas Dan Reliabilitas}

Tabel 1 Hasil Uji Validitas Kompensasi

\begin{tabular}{ccccc}
\hline No & Item & r hitung & r tabel & Keterangan \\
\hline 1 & X1.1 & 0.922 & 0.4438 & Valid \\
2 & X1.2 & 0.860 & 0.4438 & Valid \\
3 & X1.3 & 0.684 & 0.4438 & Valid \\
4 & X1.4 & 0.805 & 0.4438 & Valid \\
5 & X1.5 & 0.765 & 0.4438 & Valid \\
6 & X1.6 & 0.684 & 0.4438 & Valid \\
7 & X1.7 & 0.860 & 0.4438 & Valid \\
8 & X1.8 & 0.860 & 0.4438 & Valid \\
9 & X1.9 & 0.551 & 0.4438 & Valid \\
10 & X1.10 & 0.860 & 0.4438 & Valid \\
11 & X1.11 & 0.922 & 0.4438 & Valid \\
12 & X1.12 & 0.922 & 0.4438 & Valid \\
13 & X1.13 & 0.644 & 0.4438 & Valid \\
14 & X1.14 & 0.551 & 0.4438 & Valid \\
15 & X1.15 & 0.922 & 0.4438 & Valid \\
16 & X1.16 & 0.922 & 0.4438 & Valid \\
\hline
\end{tabular}

Sumber: Hasil penelitian yang diolah, 2019

Berdasarkan Tabel 1 diatas hasil penelitian menunjukkan bahwa $\mathrm{r}$ hitung $>\mathrm{r}$ tabel yaitu untuk $n=20$ dengan taraf signifikan 0,05 adalah 0,4438 . Dengan demikian maka, dapat dikatakan bahwa instrument variabel kompensasi valid.

Tabel 2 Uji Validitas Promosi Jabatan

\begin{tabular}{ccccc}
\hline No & Item & r hitung & r tabel & Keterangan \\
\hline 1 & X2.1 & 0.350 & 0.2816 & Valid \\
2 & X2.2 & 0.562 & 0.2816 & Valid \\
3 & X2.3 & 0.615 & 0.2816 & Valid \\
4 & X2.4 & 0.766 & 0.2816 & Valid \\
5 & X2.5 & 0.708 & 0.2816 & Valid \\
6 & X2.6 & 0.815 & 0.2816 & Valid \\
7 & X2.7 & 0.733 & 0.2816 & Valid \\
8 & X2.8 & 0.389 & 0.2816 & Valid \\
9 & X2.9 & 0.571 & 0.2816 & Valid \\
10 & X2.10 & 0.745 & 0.2816 & Valid \\
11 & X2.11 & 0.815 & 0.2816 & Valid \\
12 & X2.12 & 0.766 & 0.2816 & Valid \\
13 & X2.13 & 0.652 & 0.2816 & Valid \\
14 & X2.14 & 0.815 & 0.2816 & Valid \\
15 & X2.15 & 0.732 & 0.2816 & Valid
\end{tabular}

Sumber: Hasil penelitian yang diolah, 2019 


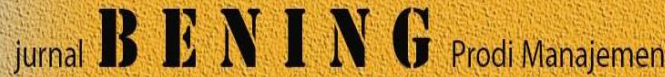

UNIVERSITAS RIAU KEPULAUAN BATAM

Tabel 2 diatas terlihat bahwa hasil uji validitas semua item pertanyaan pada variabel promosi jabatan mempunyai $r$ hitung $>\mathrm{r}$ tabel dangan taraf signifikan $\alpha=0,05$ dan nilai $r$ tabel sebesar 0,2816 , dapat disimpulkan bahwa semua pertanyaan pada variable promosi jabatan dinyatakan valid.

\section{Tabel 3 Uji Validitas Motivasi Kerja}

\begin{tabular}{lllll}
\hline No & Item & r hitung & r tabel & Keterangan \\
\hline 1 & X3.1 & 0.551 & 0.2816 & Valid \\
2 & X3.2 & 0.520 & 0.2816 & Valid \\
3 & X3.3 & 0.484 & 0.2816 & Valid \\
4 & X3.4 & 0.505 & 0.2816 & Valid \\
5 & X3.5 & 0.750 & 0.2816 & Valid \\
6 & X3.6 & 0.730 & 0.2816 & Valid \\
7 & X3.7 & 0.556 & 0.2816 & Valid \\
\hline
\end{tabular}

Sumber: Hasil penelitian yang diolah, 2019

Tabel 3 di atas terlihat bahwa hasil uji validitas semua item pertanyaan pada variable motivasi kerja mempunyai $r$ hitung $>\mathrm{r}$ tabel dangan taraf signifikan $\alpha=0,05$ dan nilai $r$ tabel sebesar 0,2816 , dapat disimpulkan bahwa semua pertanyaan pada variabel motivasi kerja dinyatakan valid.

Tabel 4 Uji Validitas Kinerja Karyawan

\begin{tabular}{lllll}
\hline No & Item & r hitung & r tabel & Keterangan \\
\hline 1 & Y1.1 & 0.712 & 0.2816 & Valid \\
2 & Y1.2 & 0.716 & 0.2816 & Valid \\
3 & Y1.3 & 0.682 & 0.2816 & Valid \\
4 & Y1.4 & 0.744 & 0.2816 & Valid \\
5 & Y1.5 & 0.683 & 0.2816 & Valid \\
6 & Y1.6 & 0.604 & 0.2816 & Valid \\
7 & Y1.7 & 0.658 & 0.2816 & Valid \\
8 & Y1.8 & 0.638 & 0.2816 & Valid \\
9 & Y1.9 & 0.682 & 0.2816 & Valid \\
10 & Y1.10 & 0.744 & 0.2816 & Valid \\
11 & Y1.11 & 0.683 & 0.2816 & Valid \\
12 & Y1.12 & 0.604 & 0.2816 & Valid \\
\hline
\end{tabular}

Sumber: Hasil penelitian yang diolah, 2019

Pada Tabel 4 di atas terlihat bahwa hasil uji validitas semua item pertanyaan pada variable kinerja karyawan mempunyai $r$ hitung $>r$ tabel dangan taraf signifikan $\alpha=0,05$ dan nilai $r$ tabel sebesar 0,2816, dapat disimpulkan bahwa semua pertanyaan pada variabel kinerja karyawan dinyatakan valid.
Tabel 5 Uji Reliabilitas

\begin{tabular}{|c|c|c|c|c|}
\hline No & Variabel & $\begin{array}{l}\text { Cronba } \\
\text { ch's } \\
\text { Alpha }\end{array}$ & $\begin{array}{l}\text { Cronbach } \\
\text { 's Alpha } \\
\text { yang } \\
\text { harus di } \\
\text { syaratkan } \\
\end{array}$ & $\begin{array}{l}\text { Keteran } \\
\text { gan }\end{array}$ \\
\hline 1 & $\begin{array}{l}\text { Kompensasi } \\
\text { (X1) } \\
\text { Promosi }\end{array}$ & 0.762 & 0.6 & Reliabel \\
\hline 2 & $\begin{array}{l}\text { Jabatan } \\
\text { (X2) }\end{array}$ & 0.761 & 0.6 & Reliabel \\
\hline 3 & $\begin{array}{l}\text { Motivasi } \\
\text { Kerja (X3) } \\
\text { Kinerja }\end{array}$ & 0.741 & 0.6 & Reliabel \\
\hline 4 & $\begin{array}{l}\text { Karyawan } \\
\text { (Y) }\end{array}$ & 0.761 & 0.6 & Reliabel \\
\hline
\end{tabular}

Pada Tabel 5 di atas dapat dilihat bahwa $r$ alpha ari masing-masing variabel $\mathrm{X} 1, \mathrm{X} 2, \mathrm{X} 3$, dan $\mathrm{Y}$ lebih besar dari 0,6. Dengan demikian dapat disimpulkan data yang telah diuji dinyatakan reliabel.

Tabel 5 One-Sample KolmogorovSmirnov Test

\begin{tabular}{lll}
\hline & & $\begin{array}{l}\text { Unstandardized } \\
\text { Residual }\end{array}$ \\
\hline $\mathrm{N}$ & & 49 \\
Normal & Mean & 0E-7 \\
Parameters & Std. & 4.16554979 \\
& Deviation & \\
Most Extreme & Absolute & .104 \\
Differences & Positive & .096 \\
Kolmogorov-Smirnov Z & .729 \\
\multicolumn{2}{l}{ Asymp. Sig. (2-tailed) } & .663 \\
\hline
\end{tabular}

a. Test distribution is Normal.

b. Calculated from data.

Sumber: Hasil pengolahan data, 2019

Berdasarkan tabel One sample Kolmogrov Smirnov diketahui nilai Asymp. Sig. (2-tailed) sebesar 0,663 > dari 0,05 (alpha) sehingga dapat disimpulkan bahwa data mempunyai sebaran yang normal.

\section{Uji Normalitas}

Berdasarkan hasil uji normalitas digambarkan pada Gambar 1. 


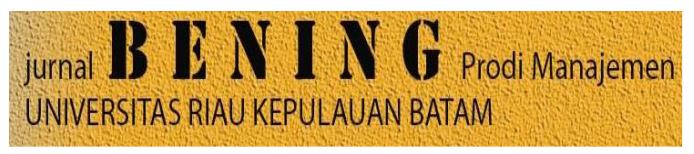

Gambar 1 Grafik Normal P-P Plot

Normal P-P Plot of Regression Standardized Residual

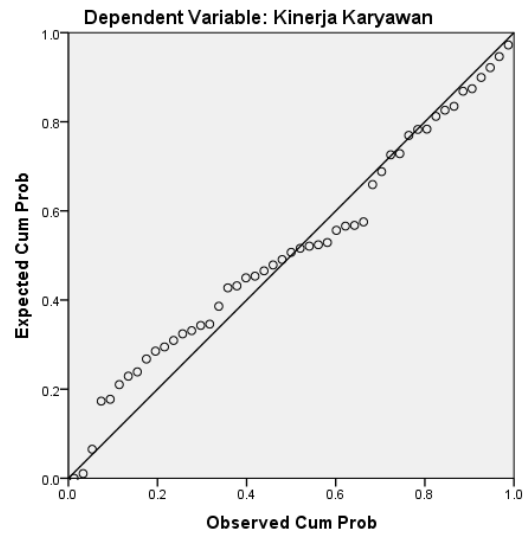

Sumber: Hasil pengolahan data, 2019

Gambar 1 di atas memperlihatkan ketentuan bahwa titik-titik data menyebar disekitar garis diagonal dan mengikuti arah garis diagonal maka dapat dikatakan data memenuhi asumsi normalitas.

\section{Gambar 2 Histogram}

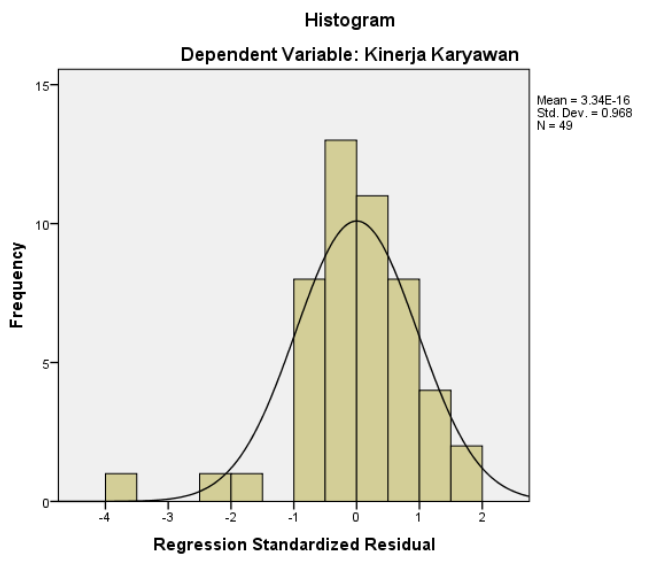

Berdasarkan Gambar 2 Grafik Histogram memberikan pola distribusi yang melenceng ke kanan yang artinya adalah data distribusi normal.

\section{Tabel 6 Uji Parsial (Uji T)}

Coefficients ${ }^{\mathrm{a}}$

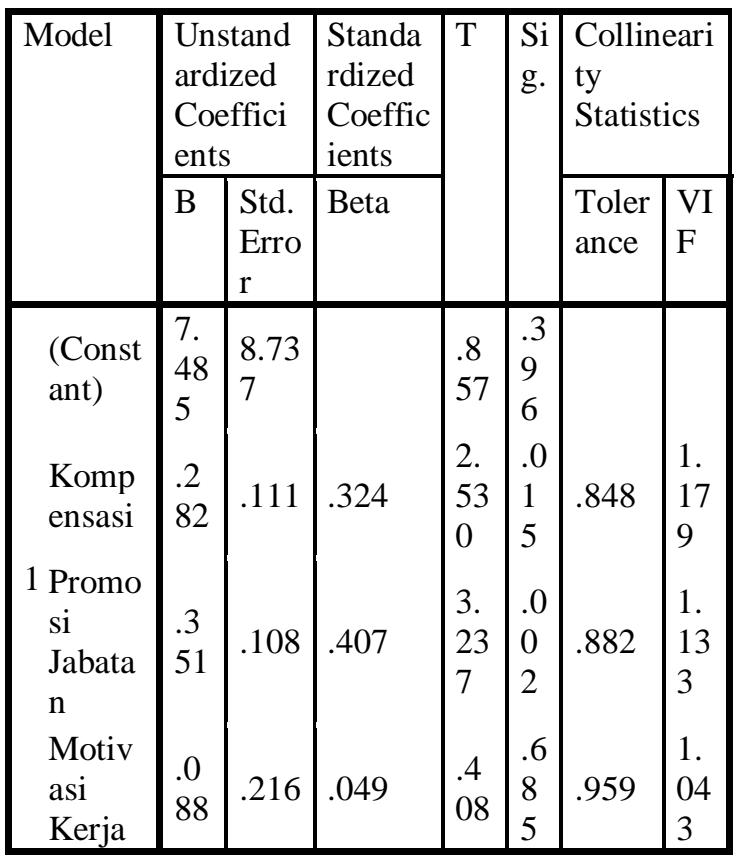

a. Dependent Variable: Kinerja Karyawan

Dari hasil Tabel 6 coefficients menunjukkan bahwa:

Variabel kompensasi (X1) nilai t hitung $2,530>\mathrm{t}$ tabel 1,679 dan nilai signifikannya $0,015>0,05$ yang berarti Ho diterima.

Ho: Kompensasi berpengaruh signifikan terhadap kinerja karyawan PT. Mega Synergy Powerindo Batam.

Ha: Kompensasi tidak berpengaruh signifikan terhadap kinerja karyawan PT. Mega Synergy Powerindo Batam.

Variabel promosi jabatan (X2) nilai $\mathrm{t}$ hitung 3,237 > t tabel 1,679 dan nilai signifikannya $0,002<0,05$ yang berarti $\mathrm{Ho}$ diterima.

Ho: Promosi jabatan berpengaruh terhadap kinerja karyawan PT. Mega Synergy Powerindo Batam.

Ha: Promosi jabatan berpengaruh tidak signifikan terhadap kinerja karyawan PT. Mega Synergy Powerindo Batam.

Variabel motivasi kerja (X3) nilai $\mathrm{t}$ hitung $0,408<\mathrm{t}$ tabel 1,679 dan nilai signifikannya $0,685>0,05$ yang berarti Ho ditolak. 
jurnal $\boldsymbol{B} \perp \mathbb{I} \perp(\boldsymbol{V}$ Prodi Manajemen UNIVERSITAS RIAU KEPULAUAN BATAM

Ho: Motivasi berpengaruh signifikan terhadap kinerja karyawan PT. Mega Synergy Powerindo Batam.

Ha: Motivasi tidak berpengaruh signifikan terhadap kinerja karyawan PT. Mega Synergy Powerindo Batam.

Uji F

Tabel 7 ANOVA ${ }^{\mathrm{a}}$

\begin{tabular}{|c|c|c|c|c|c|}
\hline Model & $\begin{array}{l}\text { Sum of } \\
\text { Squares }\end{array}$ & $\mathrm{df}$ & $\begin{array}{l}\text { Mean } \\
\text { Square }\end{array}$ & $\mathrm{F}$ & Sig. \\
\hline Regression & 73.310 & 3 & 24.437 & 1.095 & $.370^{\mathrm{b}}$ \\
\hline 1 Residual & 535.690 & 24 & 22.320 & & \\
\hline Total & 609.000 & 27 & & & \\
\hline
\end{tabular}

a. Dependent Variable: Y

b. Predictors: (Constant), X1, X2, X3

Uji $\mathrm{f}$ memperlihatkan nilai $\mathrm{f}$ sebesar $\mathrm{f}$ hitung $1,095<2,81 \mathrm{f}$ tabel dan nilai probalitas signifikan sebesar 0,370>0,05 sehingga artinya variabel kompensasi, promosi jabatan dan motivasi kerja secara simultan berpengaruh tidak signifikan terhadap variabel kinerja karyawan.

\section{KESIMPULAN}

Berdasarkan hasil penelitian dan pembahasan yang telah dilakukan, maka dapat disimpulkan:

1. Kompensasi berpengaruh tidak signifikan terhadap kinerja karyawan PT. Mega Synergy Powerindo Batam.

2. Promosi jabatan berpengaruh signifikan terhadap kinerja karyawan PT. Mega Synergy Powerindo Batam.

3. Motivasi berpengaruh tidak signifikan terhadap kinerja karyawan PT. Mega Synergy Powerindo Batam.

4. Kompensasi, promosi jabatan, dan motivasi secara simultan berpengaruh tidak signifikan terhadap kinerja karyawan PT. Mega Synergy Powerindo Batam.
Volume 6 No. 2 Tahun 2019

P-ISSN 2252-5262

E-ISSN 2614-499

\section{SARAN}

Berdasarkan hasil penelitian ini, maka disampaikan saran berikut:

PT. Mega Synergy Powerindo Batam hendaknya memperhatikan promosi jabatan agar kinerja karyawan optimal.

\section{DAFTAR PUSTAKA}

Amalia Syarah, FakhriMahendra. (2016). Pengaruh Motivasi Kerja Terhadap Kinerja Karyawan Pada PT. Gramedia Asri Media Cabang Emerland Bintaro.Jurnal Computech \& Bisnis. ISSN 2442-4943, Vol 10, No 2, Desember 2016, 119-127.

Armansyah Andi, Azis Idris, Evvy RossantyNiluh Putu. (2018). Pengaruh Kompensasi Dan Disiplin Kerja Terhadap Kinerja Pegawai Kantor BPJS Kesehatan Cabang Palu.Jurnal Ilmu Manajemen Universitas Tadulako. ISSNOnline 2443-3578/ISSN Printed 2443-1850, Vol. 4, No. 3, September 2018, 235-244.

Datu Sabar Navrathin, Adolfina, Dotulong Lucky O.H. (2017). Pengaruh Promosi Jabatan Dan Mutasi Terhadap Kinerja Pegawai (Studi Pada Pegawai Kantor Wilayah Direktorat Jenderal Perbendaharaan Provinsi Sulawesi Utara). Jurnal EMBA, ISSN 2303-1174, Vol.5 No.2 Juni 2017.

Hendro Timoti. (2018). Pengaruh Kompensasi Dan Kepuasan Kerja Terhadap Kinerja Karyawan Tetap CV. Karya Gemilang.Jurnal AGORA Vol 6, No. 1, (2018).

Laminingrum Anny Kusumo. (2016). Pengaruh Kompensasi Terhadap Motivasi Kerja Pada Karyawan Biro Pelayanan Sosial Dasar Di Sekretariat Daerah Provinsi Jawa Barat. Jurnal eProceeding of Management. ISSN: 2355-9357, Vol.3, No.2 Agustus 2016.

Latief Abdul, Rizqi Zati Muhammad, Mariana Siti. (2018). Pengaruh Kompensasi Dan Motivasi Kerja Terhadap Kinerja Karyawan Pada Pusat Penelitian Kelapa Sawit (PPKS).Jurnal 


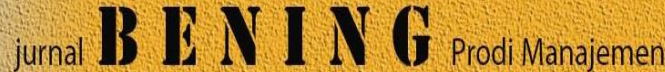

UNIVERSITAS RIAU KEPULAUAN BATAM

Sistem Informasi ISSN P: 2598-599X; E: 2599-0330.

Maulana Wahyu. (2018). Pengaruh Kepemimpinan, Kompensasi Dan Promosi Jabatan Terhadap Kinerja Karyawan Melalui Kepuasan Kerja Pada PT. Bank Jatim, Tbk Cabang Pamekasan. Makro, Jurnal Manajemen \& Kewirausahaan, ISSN 1412-2936, Vol. 3 No. 1 Mei 2018.

Nurjaman Kadar. (2014). Manajemen Personalia. Bandung. CV. Pustaka Setia.

Prabowo Bastian, Al Musadieq Mochammad, Ruhana Ika. (2016). Pengaruh Promosi Jabatan Terhadap Motivasi Kerja Dan Prestasi Kerja (Studi Pada Karyawan PT. Telkom Indonesia Witel Jatim Selatan Malang).Jurnal Administrasi Bisnis (JAB). Vol. 32 No. 1 Maret 2016.

Pudjo Wibowo Fx. (2018). Pengaruh Kompensasi Dan Motivasi Terhadap Kinerja Karyawan (Studi Kasus PT Indoraya Internasional di Yogyakarta). SAINS: Jurnal Manajemen dan Bisnis p-ISSN: 1978-2241 e-ISSN:2541-1047 Volume X, Nomor 2, Juni 2018.

Putra Udin, Hasanuddin Bakri, Wirastuti Wiri. (2018). Pengaruh Motivasi Kerja Dan Kompensasi Terhadap Kinerja Karyawan Pada PT. Balindo Manunggal Bersama Kota Palu.Jurnal Ilmu Manajemen Universitas Tadulako. ISSN Online 2443-3578/ISSN Printed 2443-1850, Vol. 4, No. 1, Januari 2018, 001-010.

Suparinah Ela. (2018). Pengaruh Mutasi Dan Promosi Jabatan Terhadap Kinerja Karyawan Pada PT Waru Kaltim Plantation Di Penajam Paser Utara. eJournal Administrasi Bisnis, 2018, 6 (2): 425-438 ISSN 2355-5408, ejournal.adbisnis.fisip-unmul.ac.id.

Syaifullah As'ad, Adhi Prasetyo Iwan. (2018). Pengaruh Kompensasi dan Motivasi Terhadap Kinerja Karyawan. Jurnal INOVASI. ISSN Print: 02167786 - ISSN.
Volume 6 No. 2 Tahun 2019

P-ISSN 2252-5262

E-ISSN 2614-499

Theodora Olivia. (2015). Pengaruh Motivasi Kerja Terhadap Kinerja Karyawan PT. Sejahtera Motor Gemilang. Jurnal AGORA. Vol. 3, No. 2, (2015). 